\title{
APPROACH TO SCORPION STINGS DURING PREGNANCY: CASE REPORT
}

\author{
GEBELIKTE AKREP SOKMALARINA YAKLAŞIM- OLGU SUNUMU
}

\author{
Ömer DEMIR 1 , Harika YUMRU ÇELIKSOY² (D), Cihan COMBA ${ }^{3}$ (D) \\ 'Erzurum Karayazı County State Hospital, Department of Gynecology and Obstetrics, Erzurum, Turkey \\ ${ }^{2}$ Kastamonu Inebolu County State Hospital, Department of Gynecology and Obstetrics, Kastamonu, Turkey \\ ${ }^{3}$ Bakırköy Dr. Sadi Konuk Education and Research Hospital, Department of Gynecology and Obstetrics, Istanbul, Turkey
}

ORCID IDs of the authors: Ö.D.: 0000-0003-4376-8733; H.Y.Ç.: 0000-0002-8936-5211; C.C.: 0000-0002-3161-2689

Cite this article as: Demir O, Yumru-Celiksoy H, Comba C. Approach to scorpion stings during pregnancy: Case report-review of literature. J Ist Faculty Med 2019;82(3):164-7. doi: 10.26650/IUITFD.2019.368394

\begin{abstract}
The aim of this article was to discuss what should be done in the case of a scorpion sting during pregnancy and the possible risks to the fetus and mother in the context of literature. At the same time a case involving a pregnant woman admitted to a county state hospital following a scorpion sting is presented. A thirtyfive-year-old, Gravida 2-Parity 1 patient in the $12^{\text {th }}$ week of gestation was admitted to the emergency department of the state hospital complaining of burning, numbness and redness on her right leg after being stung by a scorpion on the upper thigh of her right leg. Stage 1 was described as a mild stage. In this case, pregnancy was completed without any pathology development and with a healthy childbirth at term. Our studies show that although there are various, albeit insufficient results in literature, the probable outcomes associated with scorpion venom should be closely monitored. The literature on this issue is controversial and more detailed studies on clinical follow-up are needed.
\end{abstract}

Keywords: Pregnancy, scorpion sting, treatment

\section{INTRODUCTION}

Although there are many studies in literature about the effects of scorpion stings and venom, there is limited information on the fetal-maternal effects of scorpion venom in pregnancy. It is reported that there are more than 1,500 scorpion species in the world, yet only a few of them have systemic toxic effects on humans $(1,2)$.

In Turkey there are 23 species over 11 genera and it has been determined that 8 of these species are venomous (3).

\section{ÖZET}

Bu yazıda, bir ilçe devlet hastanesine akrep sokması nedeniyle başvuran bir gebe olguyu sunarken, gebelikte akrep sokması durumunda yapılması gerekenler ile fetus ve anne açısından olası risklerin literatür eşliğinde tartışılması amaçlandı. Otuz beş yaşında, Gravida 2- Parite 1, 12 haftalık gebe hasta sağ uyluk üst yan kısmından akrep sokması sonrası sağ bacakta yanma, uyuşma ve kızarıklık şikâyetiyle devlet hastanesi acil servisine başvurdu. Hastanın durumu evre 1 ile uyumlu idi. Evre 1 hafif evre olarak nitelendirilmekteydi. Bizim olgumuzda gebelik herhangi bir patoloji gelişmeden ve termde canlı ve sağlıklı bir çocuk doğumu ile tamamlandı. Sonuç olarak literatürdeki farklı ancak yetersiz sonuçlar gösteriyor ki; akrep venomunun olası etkilerine karşı olgular yakın takip edilmelidir. Bu konu hakkında literatür verileri çelişir durumdadır, klinik takip açısından daha detaylı çalışmaların da yapılması gerekmektedir.

Anahtar Kelimeler: Gebelik, akrep sokması, tedavi

After a scorpion sting, a variable clinical course can be observed from mild local findings to severe systemic findings that can threaten life. The type of scorpion, age, size, nutritional status, number of scorpion stings, depth of venom injection, proximity to the head and body, and general health status of the victim also affect the clinical situation of the poisoning.

There are many studies in literature about scorpion stings, but the information relating to the effects of scor-

Corresponding author/iletişim kurulacak yazar: itf.omerdemir@gmail.com

Submitted/Başvuru: 18.12.2017 • Accepted/Kabul: 19.04.2019 • Published Online/Online Yayın: 02.07.2019

(C) Telif Hakkı $2019 \mathrm{~J}$ Ist Faculty Med - Makale metnine jmed.istanbul.edu.tr web sayfasından ulaşılabilir.

CCopyright 2019 by J Ist Faculty Med - Available online at jmed.istanbul.edu.tr 
pion stings and venoms on the fetus and mother during pregnancy is limited. The scorpion stings seen in our country are most frequently seen in summer and in the Central Anatolia Region (4).

The scorpion stings were staged as follows: (5-7)

Stage I: Pain and/or paresthesia in the area where the scorpion struck.

Positive tap test (exacerbation of pain by touching or hitting)

Stage II: Pain and paresthesia in regions not in the area where the scorpion struck in addition to Stage 1

Stage III: Having one of the following:

a) Neuromuscular dysfunction: Sudden contraction and withdrawal in the extremities, restlessness, involuntary muscle movements

b) Cranial nerve dysfunction: Blurred vision, abnormal eye movements

c) Hypersalivation, tongue fasciculation, difficulty in swallowing, upper airway dysfunction

Stage IV: Findings of cranial nerve and neuromuscular dysfunction

Scorpion sting is generally mild in the patient and antivenom requirement is determined as $8 \%(2,4)$.

The aim of this article was to discuss what should be done in the case of a scorpion sting during pregnancy and the possible risks to the fetus and mother in the context of literature. At the same time a case involving a pregnant woman admitted to a county state hospital following a scorpion sting is presented.

\section{CASE}

A thirty-five-year-old, Gravida 2-Parity 1 patient in the $12^{\text {th }}$ week of gestation was admitted to the emergency department of the state hospital complaining of burning, numbness and redness on her right leg after being stung by a scorpion on the upper thigh of her right leg. The general condition of the patient at emergency service application was good, conscious and cooperative.

The physical examination revealed no pathology except for a $3 \times 3 \mathrm{~cm}$ area of redness at the puncture site. Fever was $36.9^{\circ} \mathrm{C}$, pulse was 82 beats $/ \mathrm{min}$, respiration was 16 beats/min, blood pressure was $120 / 60 \mathrm{mmHg}$ and routine laboratory findings were normal. An ultrasonographic evaluation of the fetus revealed a single fetus in the twelth week of gestation measured as the crownrump length of $53 \mathrm{~mm}$. No bleeding in the placental area was observed. No leukocytosis or elevation of CRP (C-reactive Protein) was detected in the blood samples.
No pathological features were found in the coagulation profile.

In the biochemical examination, the ECG (Electrocardiography) of the patient was normal and the cardiac enzymes were within normal limits.

The National Poison Counseling Center was contacted by phone and information was provided. The stage of the sting was determined first, according to the information given by the centre. The condition of the patient was consistent with stage 1 and this was described as a mild stage. Whether or not scorpion anti-serum should be given to the patient was discussed with the university hospital. It was thought that anti-serum might be needed for future systemic findings, but it was also thought that the patient should be referred to the university hospital with the possible risk of anaphylaxis and so the patient was admitted.

In order to prepare this case as a presentation, the patient's consent was obtained.

\section{DISCUSSION}

The level of poisoning developed after a scorpion sting can vary according to the type of scorpion, age, size, amount of venom, nutrition characteristics and climatic conditions $(8,9)$. Scorpions do not leave their entire venom in a single sting and so the poisoning experienced after a scorpion sting is usually mild.

Scorpion venom can also cause systemic effects as well as local effects (4).

When our national data was examined, pain, hyperemia and edema were seen to be the most common localized symptoms, while systemic symptoms were nausea, tachycardia, and vomiting (4).

The management of exposure to scorpion stings varies depending on the severity of the condition. Patients are examined at four different stages according to the severity of symptoms and signs. These stages were described in the introduction.

There are two approaches to treatment, mainly antivenom therapy and supportive therapy. Supportive treatment is analgesic, antipyretic, and antihistaminic administration. Antivenom therapy is performed in stages III and IV with $1 \mathrm{~mL}$ of antivenom adminsitered intramuscularly or intravenously. The allergic history should be questioned before the antivenom is applied. Even if the story is positive, contraindication is not made for antivenom and close follow-up is recommended $(10,11)$.

An intubation set must be available before antivenom application. The most significant side effect of this treatment is anaphylaxis and serum disease. 
If the death rate due to scorpion poison is low and since there is a risk of hypersensitivity or serum disease from the antivenom, this treatment should only be administered in cases with severe toxicity in stage III and IV cases $(10,11)$.

This case was assessed as stage I because ther was pain only in the sting area. Thus, supportive treatment was applied and antivenom was not required in follow-up. Since there are not enough studies on the fetal effects of scorpion venom or the benefits of antivenom treatment, the management of the incidents of scorpion intoxication during pregnancy should be based on the clinical stages of the events.

In this case, there was no evidence other than local burning, numbness, redness, and the clinical findings were mild.

In some animal studies, it has been found that scorpion poison has adverse effects on fetal and maternal health (12).

In a study of pregnant rats with $L$. quinquestriatus scorpion venom by Marei and Ibrahim, it was expressed that the uterus is more sensitive to scorpion venom during early gestation and leads to uterine contractions (13).

In the same research, particularly in the scorpion venom, 5-hydroxytryptamine was reported to be responsible for abortion in the first trimester and that 5-hydroxytryptamine antidote should be administered along with antivenom in the treatment (13).

Studies in the literature on scorpion venom: Meki et al. showed that uterine contractions are triggered by the presence of a peptide that increases the effect of bradykinin (14), Mendonca et al. showed that uterine contractions are triggered by Toxin T1 (15).

However, other than these, there is no clear literature on the teratogenic effects.

Ismail et al., after studies on pregnant rats and especially after scorpion venom exposure on $9^{\text {th }}$ and $11^{\text {th }}$ days of gestation, found the following: low birth weight, absence of cervical vertebra 1, ossification defects, and the development of the skull of the trachea on the fetus (16).

Güler et al. found that pregnancies of 23 and 32 weeks of age, which were accepted as post-scorpion stage I by pregnancy, were completed smoothly and a healthy baby was brought into the world (17).

However, there is no clear indication in the literature about the occurrence of post-bite teratogenic effects or the time associated with abortus development.In our case, the pregnancy was advanced without any fetal pathology, and a healthy child was born at term.

\section{CONCLUSION}

In conclusion, scorpion stings rarely have serious consequences, often with mild clinical course. Scorpion venom causes local effects as well as systemic effects. It was reported that scorpion venom increases uterine contractions in the early stages of pregnancy (13). In addition, studies on animal models have revealed possible teratogenic effects (16). However, there is no clear data on gestational age in terms of the development of uterine contractions after scorpion stings and possible teratogenic effects. Observation and supportive treatment are sufficient in Stage I and Stage II cases. In stage III and IV trials, scorpion antiserum should be administered as soon as possible regardless of gestational week. However, probable events should be closely monitored against possible effects of scorpion venom. Literature on this issue is controversial and more detailed studies on clinical follow-up are needed.

Ethics Committee Approval: This study was not approved by an ethical committee. (Case Report)

Informed Consent: Written consent was obtained from the participants.

Peer Review: Externally peer-reviewed.

Author Contributions: Conception/Design of Study- Ö.D. C.C., H.Y.Ç.; Data Acquisition- Ö.D.; Data Analysis/Interpretation- Ö.D.; Drafting Manuscript- Ö.D., C.C., H.Y.Ç.; Critical Revision of Manuscript- C.C., H.Y.Ç.; Final Approval and Accountability- Ö.D., C.C., H.Y.Ç.; Technical or Material Support- Ö.D.; Supervision- Ö.D.

Conflict of Interest: Authors declared no conflict of interest.

Financial Disclosure: Authors declared no financial support.

Etik Komite Onayı: Etik komite onayı alınmamıştır. (Olgu sunu$\mathrm{mu})$

Bilgilendirilmiş Onam: Katılımcılardan bilgilendirilmiş onam alınmıştır.

Hakem Değerlendirmesi: Dış bağımsız.

Yazar Katkıları: Çalışma Konsepti/Tasarım- Ö.D., C.C., H.Y.Ç.; Veri Toplama- Ö.D.; Veri Analizi/Yorumlama- Ö.D.; Yazı TaslağıÖ.D., C.C., H.Y.Ç.; İçeriğin Eleştirel İncelemesi- C.C., H.Y.Ç.; Son Onay ve Sorumluluk- Ö.D., C.C., H.Y.Ç.; Malzeme ve Teknik Destek- Ö.D.; Süpervizyon- Ö.D.

Çıkar Çatışması: Yazarlar çıkar çatışması beyan etmemişlerdir.

Finansal Destek: Yazarlar finansal destek beyan etmemişlerdir. 


\section{REFERENCES}

1. Otero R, Navío $E$, Céspedes FA, Núñez MJ,Lozano L, Moscoso ER, et al. Scorpion envenoming in two regions of Colombia: clinical, epidemiological and therapeutic aspects. Trans R Soc Trop Med Hyg 2004;98(12):742-50. [CrossRef]

2. Ellenhorn MJ, Barceloux DG. Natural toxins. Medical Toxicology: Diagnosis and Treatment of Human Poisoning. 1st ed. New York: Elsevier, 1988;1152-4.

3. Yağmur E.A., Koç H, Kunt K.B. Description of a new species of Leiurus Ehrenberg, 1828 (Scorpiones: Buthidae) from Southeastern Turkey, Euscorpius, 2009; 85:1-20. [CrossRef]

4. Cesaretli Y, Ozkan O. Scorpion stings in Turkey: epidemiological and clinical aspects between the years 1995 and 2004. Rev Inst Med Trop Sao Paulo 2010;52(4):21520. [CrossRef]

5. Holve S. Treatment of snake, insect, scorpion and spider bites in the pediatric emergency department. Curr Opin Pediatr 1996;8(3):256-60. [CrossRef]

6. Karalliedde L. Animal toxins. Br J Anaesth 1995;74(1):31927. [CrossRef]

7. Joe G. Scorpioni. In: Olson KR, editor. Intossicazioni acute. Veleni, farmaci e droghe. Milano: Springer; 1999;298-9.

8. Gümüştekin M. [Environmental toxins: animal bites and stings]. Turkiye Klinikleri J Pharmacol Special Topics 2003;1(1):53-7.

9. Kurtoğlu S. [Scorpion stings and treatment]. Zehirlenmede Tanı ve Tedavi. Yayın No: 30. Birinci Baskı. Kayseri: Erciyes Üniversitesi Yayınları; 1992. p.539 -48.
10. Doğanay $Z$, Karataş AD, Baydın A, Bildik F, Aygün D. [ls administration of antivenin necessary for all cases of scorpion envenomation? A case report]. Turkish Journal of Emergency Medicine 2006;6(2):76-80.

11. Bemstein JN. Antivenom (scorpion and spider).In: Goldfrank LR, Flomenbaum NE, Lewin NA, Howland MA, Hoffman RS, Nelson LS, eds. Goldfrank's Toxicology Emergency.7th ed. New York: McGraw-Hill. 2002;1589-91.

12. Ben Nasr H, Serria H, Chaker S, Riadh B, Zouheir S, Kamel $J$, et al. Some biological effects of scorpion envenomation in late pregnant rats. Exp Toxicol Pathol 2009;61(6):573-80. [CrossRef]

13. Marei ZA, Ibrahim SA. Stimulation of rat uterus by venom from the scorpion $L$. quinquestriatus. Toxicon 1979;17(3):251-8. [CrossRef]

14. Meki AR, Nassar AY, Rochat H. A bradykininpotentiating peptide (peptide K12) isolated from the venom of Egyptian scorpion Buthus occitanus. Peptides 1995;16(8):1359-65. [CrossRef]

15. Mendonça M, Da Luz MM, Freire-Maia L, Cunha-Melo JR. Effect of scorpion toxin from Tityus serrulatus on the contraction of the isolated rat uterus. Toxicon 1995;33(3):355-61. [CrossRef]

16. Ismail M, Ellison AC, Tilmisany AK. Teratogenicity in the rat of the venom from the scorpion Androctonus amoreuxi (Aud. \& Sav.). Toxicon 1983;21(2):177-89. [CrossRef]

17. Güler A, Karadaş S, Kurdoğlu Z. [Approach to scorpion stings during pregnancy: two cases]. J Turk Soc Obstet Gynecol 2011;8(3):2058. [CrossRef] 